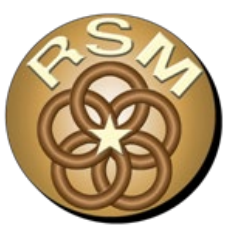

\title{
Reservoir Sediment Management and Analysis Workshop for Engineers
}

\author{
by John Shelley, Paul Boyd, Stanford Gibson, lan Floyd, \\ Blair Greimann, Marielys Ramos-Villanueva, and Travis Dahl
}

PURPOSE: This U.S. Army Corps of Engineers (USACE) National Regional Sediment Management Technical Note (RSM-TN) summarizes a Regional Sediment Management University training workshop held on the topic of reservoir sediment management in Lawrence, Kansas. The workshop included 4.5 days of classroom lectures, hands-on modeling exercises, case study examples, and a field trip.

INTRODUCTION: Most US dams were designed to trap and store sediment over a pre-determined sediment design life of 50 to 100 years. Over half of the USACE dams have now passed their 50-year mark, and the need for sediment management is becoming more evident. The strategy to trap and store sediment while starving downstream channels is not sustainable and will lead to both a significant increase in operations and maintenance costs and an eventual complete loss of reservoir benefits. Reservoir sediment management is a necessity if the level of benefits provided by these reservoirs is to be sustained. Engineers must be prepared to perform technical analyses and make informed recommendations related to reservoir sediment management activities.

During 11-15 June 2018, the USACE RSM program provided a first-of-its-kind training workshop for engineers on reservoir sediment management. Forty-three engineers attended, with robust participation from 16 USACE districts and research laboratories. Other agencies participating included the U.S. Bureau of Reclamation (USBR), Nebraska Department of Natural Resources, the Kansas Water Office, the Kansas Biological Survey, the Kansas Department of Health and Environment, and Kansas State University. While the focus of this workshop was managing sediment in existing reservoirs, the same principles would apply for new projects as well.

WORKSHOP AGENDA: The workshop provided engineers a global view of the impacts of reservoir sediment accumulation and an overview of reservoir sedimentation mechanics. In-depth discussions followed regarding how to develop the Future Without Project (FWOP) condition, the array of potential solutions, screening methods for sediment management options, conducting flushing analyses and hydrosuction analyses, and the environmental implications with and without sediment management. The workshop included lectures by USACE and USBR subject matter experts, case studies from around the world, video footage from different types of US sediment management projects, hands-on modeling and non-modeling computational workshops, breakout groups, and a site visit to witness a reservoir silt flush. The 4.5-day workshop Course Agenda is presented in Table 1. PowerPoint presentations are available at the Regional Sediment Management website https://rsm.usace.army.mil. Solutions for Sediment Related Challenges

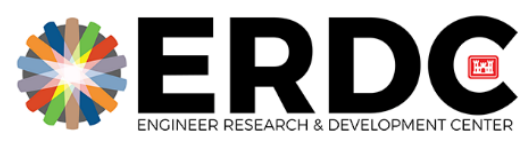


ERDC/TN RSM-19-8

November 2019

\section{Table 1. Workshop course agenda.}

\section{Monday Session}

HEC-RAS steady and unsteady flow refresher (Dr. Stanford Gibson, USACE Hydrologic

Engineering Center [IWR-HEC])

Reservoir sedimentation problems (Dr. John Shelley, USACE Kansas City District [NWK])

Reservoir sedimentation case studies from the Bureau of Reclamation (Dr. Blair Greimann,

U.S. Bureau of Reclamation [USBR])

Reservoir sedimentation mechanics (Dr. Stanford Gibson, USACE-IWR-HEC)

Computing volume change in reservoirs (Dr. Paul Boyd and Mr. Benjamin Ream USACE

Omaha District [NWO])

\section{Tuesday Session}

Pressure flush site visit to Blue Springs Lake

Pressure flushing of reservoir sediment (Dr. Blair Greimann, USBR)

Non-modeling techniques to develop the Future Without Project (Dr. John Shelley, USACENWK)

Reservoir sediment modeling with 1D morphological models (Dr. Stanford Gibson, USACEIWR-HEC)

\section{Wednesday Session}

Workshop on creating a FWOP using HEC-RAS (Dr. Stanford Gibson, USACE-IWR-HEC)

Overview of reservoir sediment management methods (lan Floyd, U.S. Army Engineer

Research and Development Center [ERDC], Coastal and Hydraulics Laboratory [CHL])

Upstream sediment reduction (lan Floyd, USACE-ERDC-CHL)

Screening level analysis for reservoir sediment management (Marielys Ramos-Villanueva,

USACE-ERDC-CHL)

Drawdown flush operations and modeling (Dr. Stanford Gibson, USACE-IWR-HEC)

\section{Thursday Session}

Hydrosuction sediment removal systems (Dr. John Shelley, USACE-NWK)

Reservoir sediment routing (Dr. Stanford Gibson, USACE-IWR-HEC)

Turbidity current venting (Marielys Ramos-Villanueva, USACE-ERDC-CHL)

Dredging (lan Floyd, USACE-ERDC-CHL)

Bypass channels (Dr. Paul Boyd, USACE- NWO)

Water injection dredging (Dr. John Shelley, USACE-NWK)

Breakout groups-Sediment solutions for Gavins Point Dam, Black Canyon Diversion, and Lake Sumner

\section{Friday Session}

Downstream channel impacts of reservoir sediment management (Dr. John Shelley, USACENWK)

Multi-dimensional modeling (lan Floyd, USACE-ERDC-CHL)

The Regional Sediment Management program (Dr. Paul Boyd, USACE- NWO)

How to engage the experts and additional topics

Workshop evaluation 
TEACHING METHODS: This workshop incorporated multiple teaching methods to help the students learn and retain information. Presentations included case studies from around the world, and video footage from sediment management projects at US reservoirs (Figure 1). To help students better internalize key concepts, the workshop featured thought experiments-quick exercises that challenge participants to discuss, debate, and publically defend their answers to nuanced, often non-intuitive, sediment problems (see Figure 2).

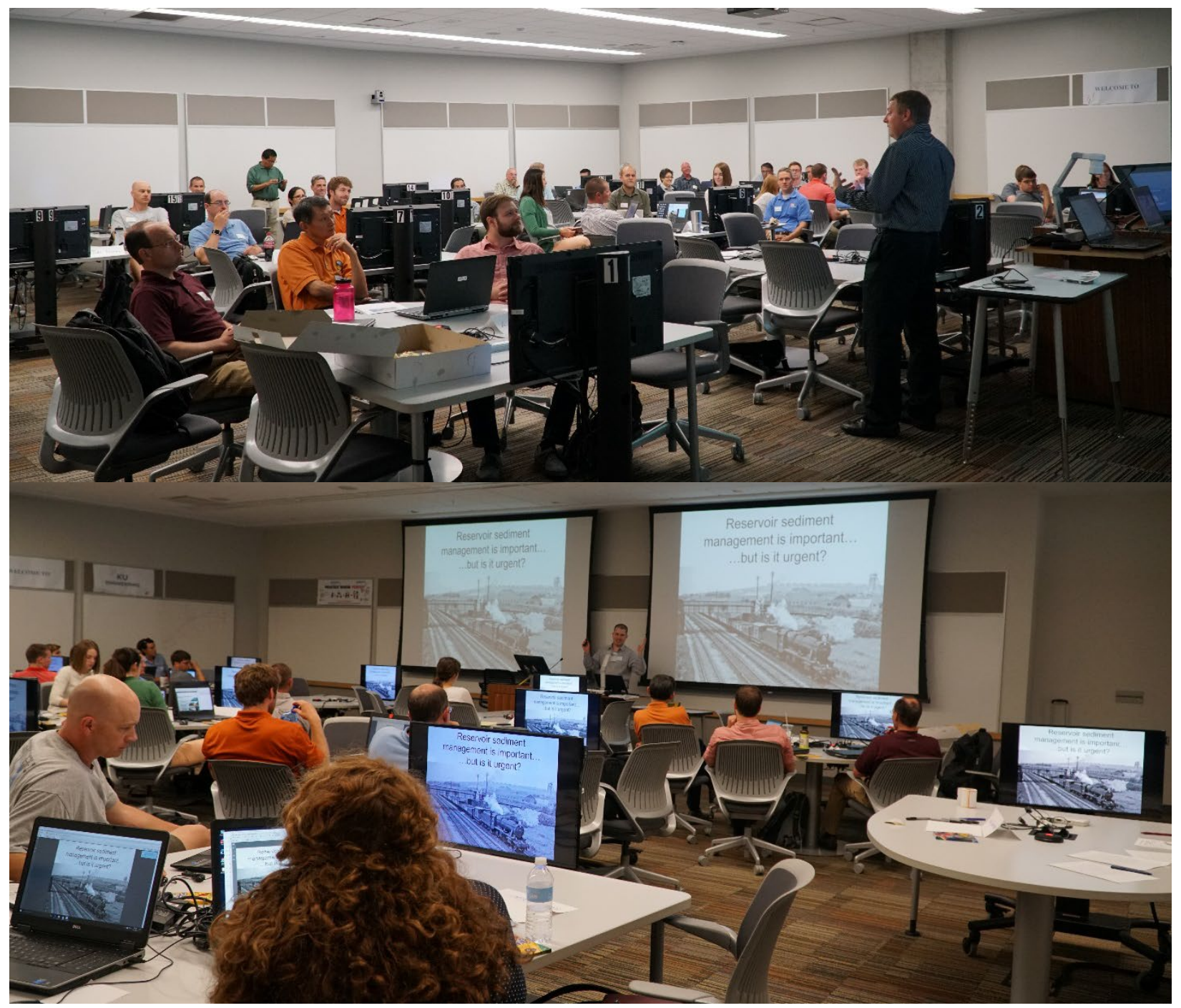

Figure 1. Workshop training presentations. 


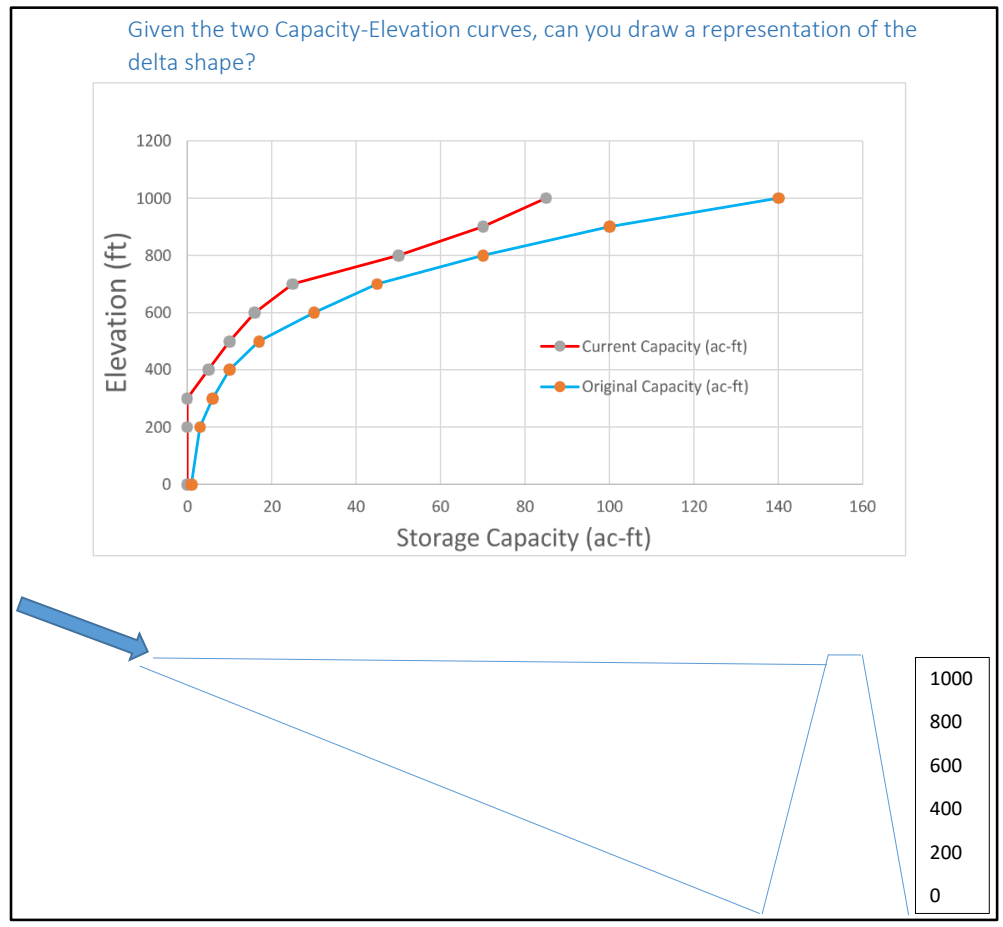

Figure 2. One of the thought experiments participants answered during the workshop.

Participants received hands-on experience in generating a FWOP condition and in analyzing potential solutions using both empirical (non-modeling) approaches and USACE, Water Resources Institute, Hydrologic Engineering Center River Analysis System (HEC-RAS) onedimensional mobile bed modeling. In breakout groups, participants practiced selecting technically feasible alternatives for one of three hypothetical reservoirs (Figure 3). This is an especially important skill as the engineers participated in the USACE Specific, Measurable, Attainable, Riskinformed, and Timely planning process, which leans more heavily on engineering judgment in the initial stages of a study.

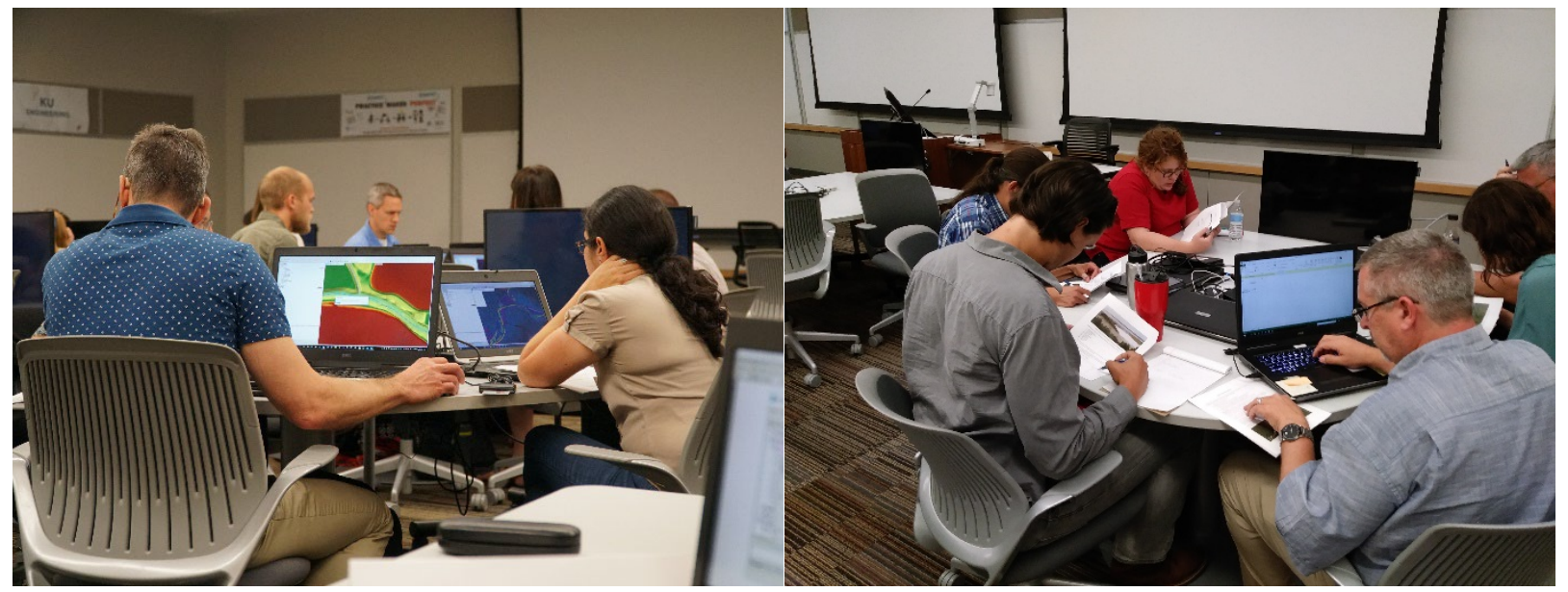

Figure 3. Workshops (left) and breakout groups (right). 
SITE VISIT TO A RESERVOIR SILT FLUSH: The workshop included a site visit to witness a pressure flush at Blue Springs Lake in Blue Springs, Missouri (Figure 4). At this USACE project, accumulated sediments near the emergency drawdown gate must be removed frequently, or the gate will be inoperable. Occasional silt flushes (also known as pressure flushes) remove this sediment. These silt flushes involve deploying an emergency bulkhead, opening and then closing the drawdown gate, allowing water to fill the chamber between the drawdown gate and the bulkhead, raising the bulkhead to an opening of 5 inches, then over the course of a few minutes, operating the drawdown gate through a complete cycle from closed to fully open back to closed. This flushes out sediment from the immediate vicinity of the drawdown gate but removes very little sediment from the rest of the reservoir.

Silver carp in the downstream channel reacted to the flush with their characteristic jumping response (Figure 5). It is possible they were reacting to the low levels of dissolved oxygen available in the first flush of stagnant water from the lake bottom. The jumping lessened as the flush continued, suggesting a rebound in dissolved oxygen after the start of the flush (a phenomenon documented at other lakes). Video footage of the pressure flush and the fish response is available at https://youtu.be/qPKpueit7Qo.

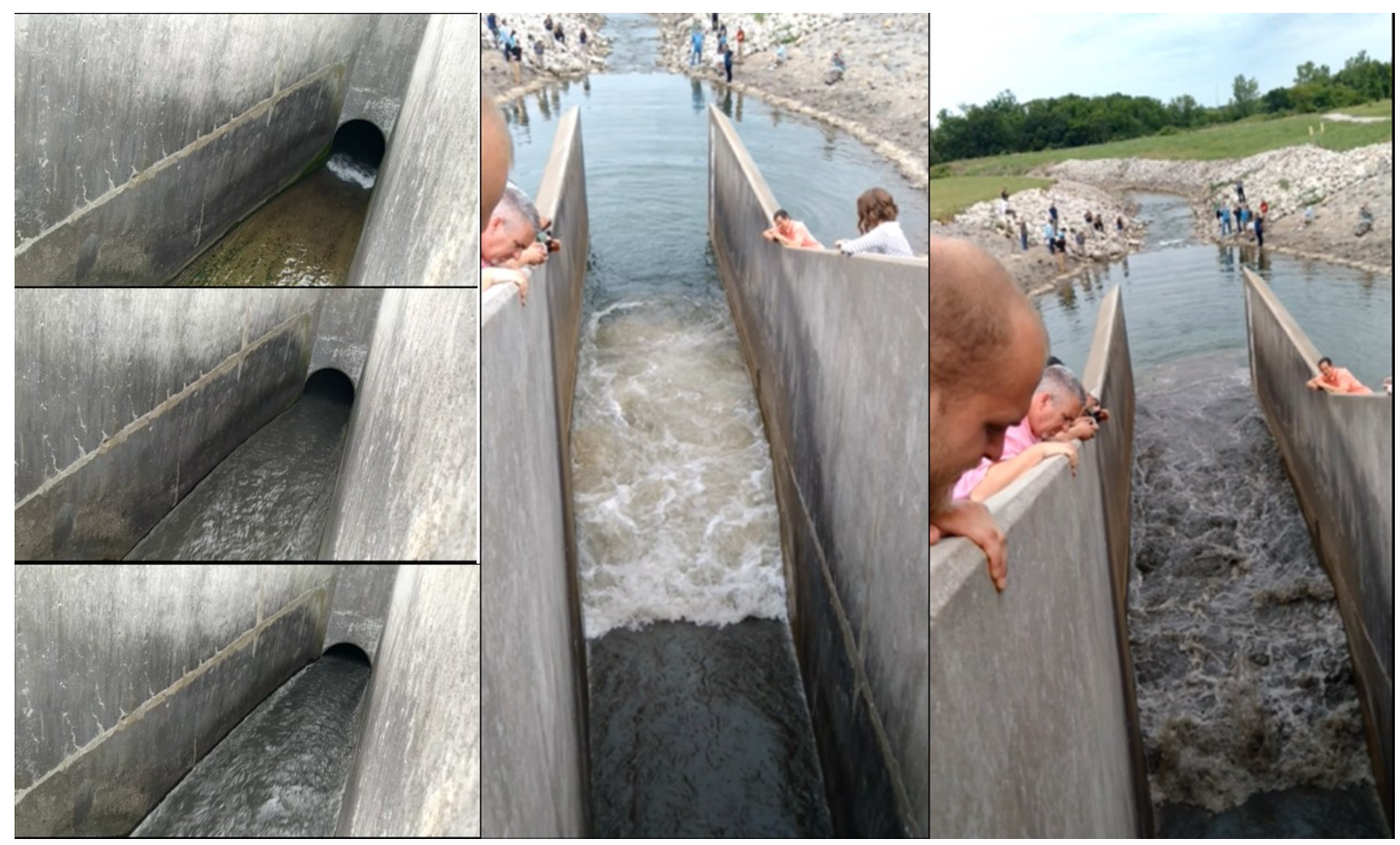

Figure 4. Silt flush at Blue Springs Lake, Missouri. 


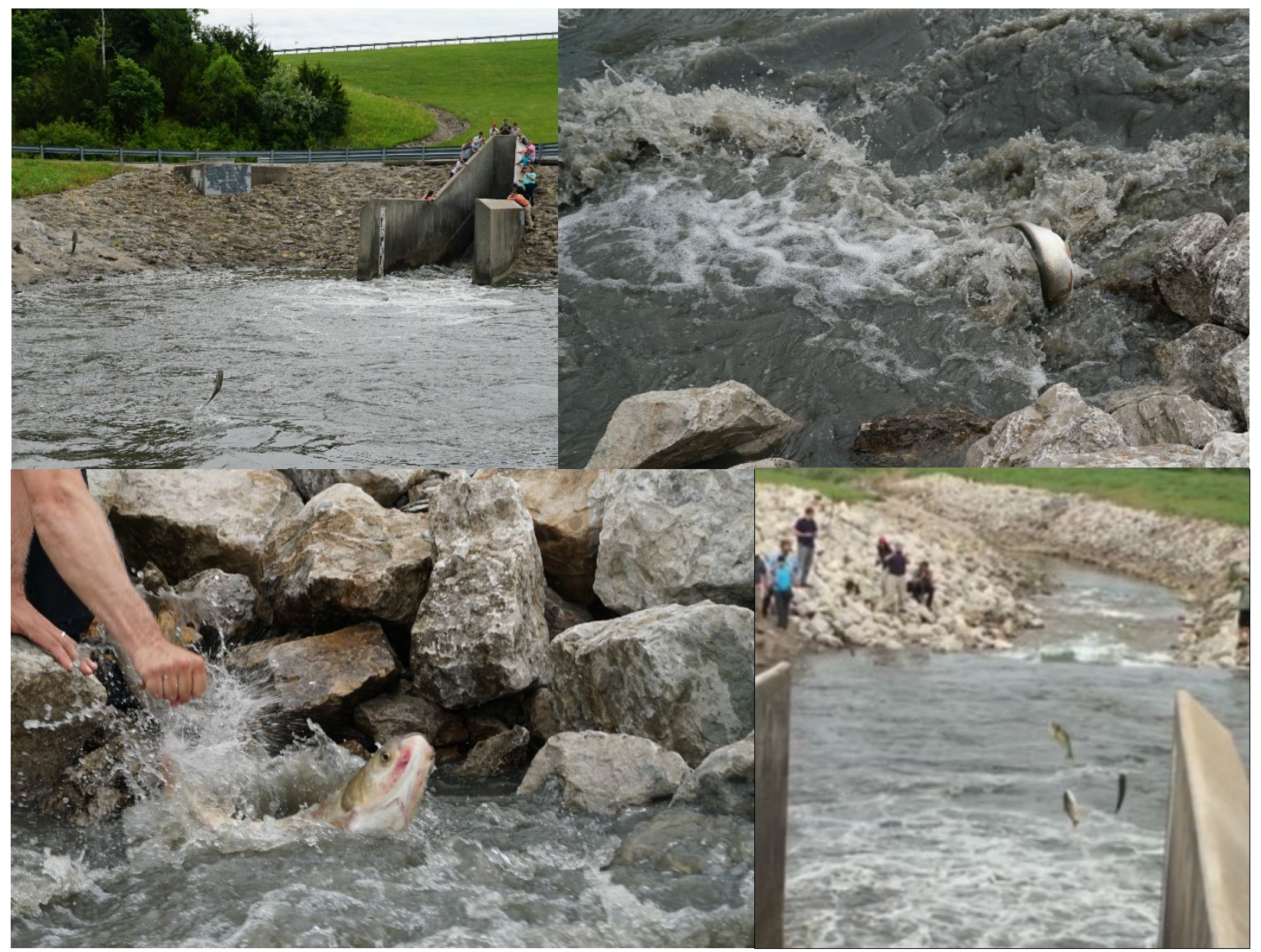

Figure 5. Response of silver carp to the arrival of the sediment plume.

An attempt was made to collect data before, during, and after the flush. Due to short notice, the district's multi-beam operator was unable to assist, so the pre- and post-flush surveys were accomplished via single beam sonar. Unfortunately, the single-beam sonar track lines were not sufficiently dense immediately near the intake to determine any change in reservoir volume.

FEEDBACK AND SUGGESTIONS: This section summarizes the feedback forms that participants filled out the final day of the workshop. Thirty-four respondents provided feedback.

Knowledge Self-Assessment. How would you rate your knowledge of reservoir sedimentation issues before and after the workshop? Participants arrived at the workshop with varying levels of knowledge of reservoir sedimentation issues (ranging from 1 to 10). The mean score rose from 3.7 to 7.2 (Figure 6). 


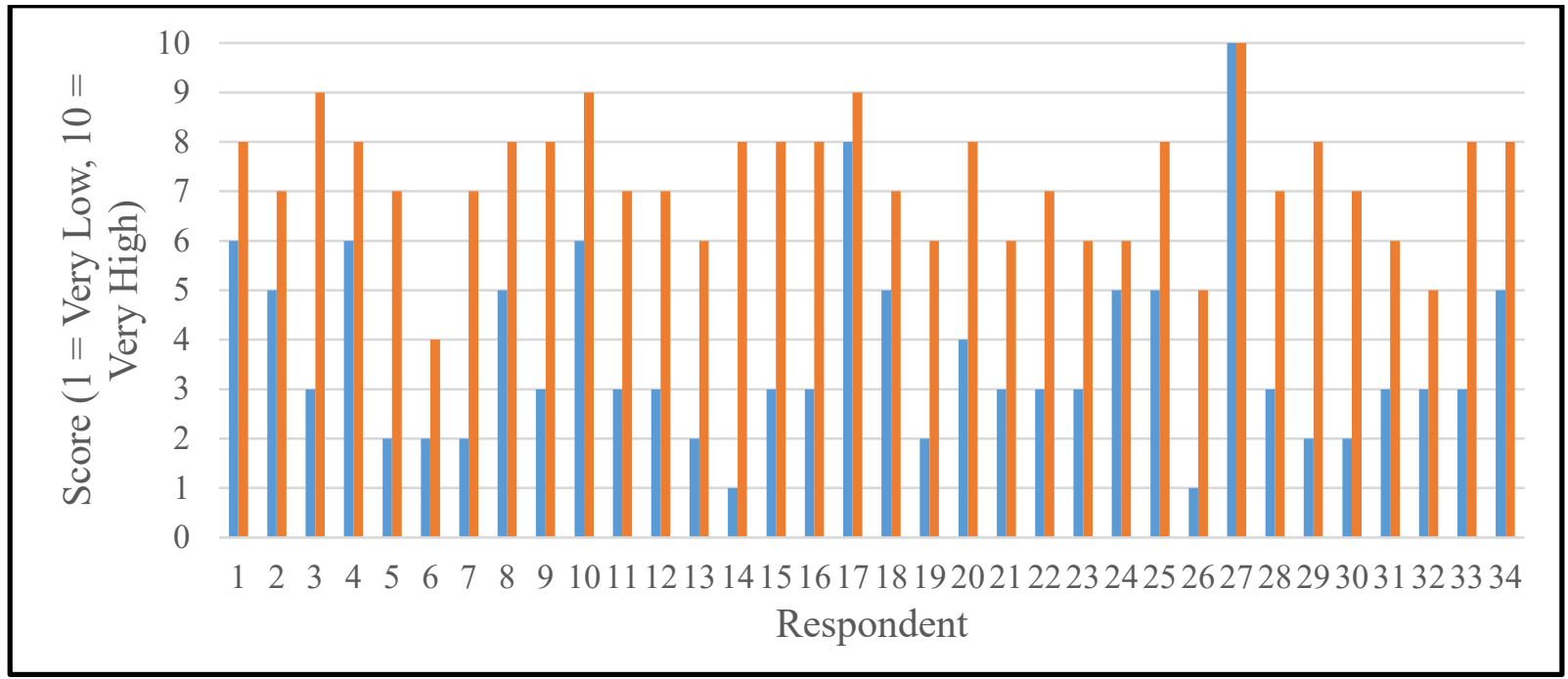

Figure 6. Self-assessment of knowledge of reservoir sedimentation issues before and after attending the workshop.

Teaching Effectiveness. The workshop intended to educate and to train. Table 2 summarizes answers to the questions related to how well the workshop conveyed information, and the participant's confidence level to actually perform the analyses required. $1=$ worst $/$ least and $10=$ best/most.

\section{Table 2. Participants' feedback on the effectiveness of the workshop at explaining major themes, and in their confidence.}

\begin{tabular}{|c|c|c|c|c||}
\hline \hline & $\begin{array}{c}\text { How well did the } \\
\text { workshop } \\
\text { convey the } \\
\text { problems } \\
\text { associated with } \\
\text { reservoir } \\
\text { sedimentation? }\end{array}$ & $\begin{array}{c}\text { How well did } \\
\text { the workshop } \\
\text { provide you an } \\
\text { overview of } \\
\text { possible } \\
\text { management } \\
\text { actions? }\end{array}$ & $\begin{array}{c}\text { How confident are } \\
\text { you in your ability to } \\
\text { create an FWOP } \\
\text { condition (within the } \\
\text { limits of available } \\
\text { data)? }\end{array}$ & $\begin{array}{c}\text { How confident are you } \\
\text { in your ability to } \\
\text { numerically assess } \\
\text { promising sediment } \\
\text { options? }\end{array}$ \\
\hline $\begin{array}{c}\text { Number of } \\
\text { Respondents }\end{array}$ & 34 & 34 & 34 & 34 \\
\hline Minimum & 6 & 6 & 2 & 3 \\
\hline Maximum & 10 & 10 & 10 & 9 \\
\hline Mean & 8.6 & 8.8 & 6.8 & 6.5 \\
\hline
\end{tabular}

Feedback on the Site Visit. Participants' written responses relative to the site visit were very positive. Participants noted the value in seeing sediment actions first hand, particularly for engineers who do not often get out to see reservoir projects. One participant noted, "I knew it was an anaerobic environment at the bottom of the lake, but the point struck home when I smelled the discharge." Multiple participants requested to see the data quantifying the effect of the flush. For future workshops, presenting the data during the workshop would require a quick turnaround on the data processing but would add value to the site visit. 
What Topics Should Have Been Included or Covered in More Detail? Most participants stated that the class covered the appropriate topics and that the level of detail was appropriate. Several expressed a desire for more information and practice with the numerical sediment modeling aspects, including modeling with Adaptive Hydraulics (AdH). Engineers who analyze reservoir sedimentation issues need to be adequately trained in USACE sedimentation models HEC-RAS and AdH. Such training typically takes multiple weeks. At the time of the workshop, no dates and locations for upcoming courses were available to provide to interested students.

Others requested more detail on upstream stabilization measures and on dredging techniques. The workshop included lectures on these topics. However, this workshop was not designed to replace the week-long Proponent-Sponsored Engineer Corps Training (PROSPECT) courses on these subjects. In the future, these lectures should be revised to better focus on reservoir applications, and the dates for the week-long PROSPECT courses should be made available to participants.

Instructor Feedback. The instructors' feedback echoed the student feedback: The workshop effectively communicated the problems of reservoir sedimentation and equipped engineers to quickly screen and assess potential solutions. The instructors suggest that in addition to this class, participants attend existing USACE training courses on sediment modeling, dredging, and bank stabilization. For future classes, the instructors should have dates and locations for those additional classes ready to communicate to participants. The instructors recommend this class be repeated every other year, alternating with a less technical course for planners, managers, and regulators. Furthermore, the instructors suggest that engineers beginning to address reservoir sedimentation issues seek hands-on involvement and mentoring from USACE sedimentation experts.

CONCLUSION: The training workshop held 11-15 June 2018 was highly successful in educating and training a group of engineers in the issues of reservoir sediment management. The workshop included presentations, case studies, breakout groups, and a field site visit. Given the widespread nature of the problems with reservoir sedimentation, additional workshops are recommended. The participant and instructor feedback in this document can help improve future classes.

ADDITIONAL INFORMATION: This RSM-TN was prepared by Dr. John Shelley, USACE, Kansas City District; Dr. Paul Boyd, USACE, Omaha District; Dr. Stanford Gibson, USACE, Institute for Water Resources Hydrologic Engineering Center; Blair Greimann, U.S. Bureau of Reclamation Technical Service Center; and Ian Floyd, Marielys Ramos-Villanueva, and Travis Dahl, U.S. Army Engineer Research and Development Center, Coastal and Hydraulics Laboratory. The training was conducted as an activity of the USACE National RSM program, a Navigation Research, Development, and Technology Transfer portfolio program administered by Headquarters, USACE. For information on the RSM program, please consult http://rsm.usace.army.mil or contact the USACE National RSM Program Manager, Katie Brusché, Katherine.E.Brutsche@erdc.dren.mil. For information regarding this RSM-TN, please contact John Shelley,john.shelley@usace.army.mil. 
This technical note should be cited as follows:

Shelley, John, Paul Boyd, Stanford Gibson, Ian Floyd, Blair Greimann, Marielys Ramos-Villanueva, and Travis Dahl. 2019. Reservoir Sediment Management and Analysis Workshop for Engineers. ERDC/TN RSM-19-8. Vicksburg, MS: U.S. Army Engineer Research and Development Center. http://dx.doi.org/10.21079/11681/34503

NOTE: The contents of this technical note are not to be used for advertising, publication, or promotional purposes. Citation of trade names does not constitute an official endorsement or approval of the use of such products. 